\title{
A New Genus and Species Record of Geometrid Moth (Lepidoptera) from Turkey
}

\author{
Erdem SEVEN \\ Department of Gastronomy and Culinary Arts, School of Tourism and Hotel Management, \\ Batman University, 72060, Batman, TURKEY \\ e-mail: erdem_seven@hotmail.com \\ ORCID ID: 0000-0002-7587-5341
}

\begin{abstract}
Kresnaia beschkovi (Ganev, 1987), which has a restricted distribution in Europe and south-western Asia, is recorded for the first time from Turkey. The species is active at night and was collected in oak forest by a UV light trap in 2018 from Batman province. It has been determined with extremely low population in the cold month. Figures of the adult male and its genitalia are illustrated. The new distributional data and ecological notes are discussed.
\end{abstract}

Key words: Fauna, Kresnaia, Kresnaia beschkovi, Lepidoptera, Ennominae, Turkey. 


\section{INTRODUCTION}

Agriopis beschkovi was described in 1987 by Ganev and later, it was transferred by Leraut (2009) to the genus Kresnaia. The species is diagnosed on the male holotype and male paratypes from south-western Bulgaria. However, the female of the species was described and published after a long time by Petschenka, Tavakoli, \& Trusch (2006) from west of Iran, on the external characters and genitalia morphology. The distribution area of the species is quite limited in Europe and it was not known in Anatolia (Koçak \& Kemal, 2018; Müller et al, 2019; Seven, 2019). In this paper, the monotypic species Kresnaia beschkovi (Ganev, 1987) is new reported in the Turkish fauna.

Kresnaia beschkovi is active at night and attracted to light. The species is univoltine and fly from mid-November to early December (Müller et al, 2019). In western Iran the larvae feed from early March to until mid-May. The adults occur in December and January in the oak forests. The larvae are monophagous and feed on trees and shrubs of Quercus brantii and Q. infectoria (Fagaceae) in western Iran (Petschenka et al, 2006).

\section{MATERIAL AND METHOD}

The investigated material was collected in 2018 from Sason district of Batman province, south-eastern Turkey. The specimen was captured by a simple UV light trap, killed by ethyl acetate, pinned, labeled, and stretched as museum material according to standard entomological methods. External morphology of the species was photographed with a Fujifilm Finepix HS30 EXR digital camera. Preparations of male genitalia was carried out following Robinson (1976), embedded as permanent slides in Euparal and photographed with a Nikon SMZ1000 stereomicroscope. Original description (Ganev, 1987) and studies of Petschenka et al, 2006; Leraut, 2009; Müller et al, 2019 were followed for identification and taxonomy of the species. The examined material is deposited in the collection of Batman University (BTU), Faculty of Science and Arts, Department of Biology, Entomology Laboratory, Turkey.

\section{RESULTS}

\section{Kresnaia Leraut, 2009}

Kresnaia Leraut, 2009, Moths of Europe, Volume 2, Geometrid moths, p. 122. Type species: Agriopis beschkovi Ganev, 1987.

Kresnaia beschkovi (Ganev, 1987) (Fig. 1.)

Agriopis beschkovi Ganev, 1987: Entomofauna 8(18): 273-275, figured (p. 174), Kressna Gorge, south-western Bulgaria. Holotype: male.

Material examined. South-eastern Turkey, Batman, Sason, Kelhasan Mt., 1160 m, 38¹8'26" N,

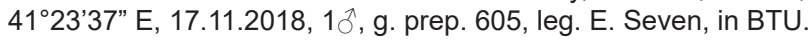


Diagnosis. Male: Wingspan $30 \mathrm{~mm}$. Antennae bipectinate. Head quite small, ground colour grey, eyes well developed. Proboscis and labial palpi small. Forewing comparatively narrow, background grey, mottled with dark grey scales. Post and antemedial lines distinct and darker grey. Postmedial line with light grey edging. Medial line dark grey, scattered. Hindwing paler and proportionally broad.

Male genitalia. Uncus long, apically slightly curled, tip round, at base wide. Gnathos forming ventrally two unfused strips. Tegumen quite long. Valva narrow, elongate, in centre slightly narrower, at base wider, tip rounded. Costa sclerotized. Vinculum well developed. Saccus rounded, at base flattened. Juxta quite small, bifid. Aedeagus narrow, long, curved. Vesica with small cornuti.

Phenology. The male specimen of Kresnaia beschkovi (Ganev, 1987) was collected in November. The average temperature in long measurement period (1959-2019) for this month is about $9.5^{\circ} \mathrm{C}$ and the mean precipitation is $54.8 \mathrm{~mm}$ in Batman province (Republic of Turkey Ministry of Agriculture and Forestry, 2020). The collection field, Sason district (Kelhasan Mt.) is a cooler area. The captured sample of $K$. beschkovi shows a same activity pattern as reported by the collection dates mentioned by Ganev (1987) and Petschenka et al, (2006).

Habitat. The known and collection locations of Kresnaia beschkovi (Ganev, 1987) are similar. In Europe, it occurs on slopes including Fraxinus ornus (Oleaceae), Juniperus excelsa, J. oxycedrus (Cupressaceae), Pistacia terebinthus (Anacardiaceae), Paliurus spina-christi (Rhamnaceae), Quercus pubescens, Q. virgiliana (Fagaceae) and, flies from 200 up to $585 \mathrm{~m}$ (Müller et al, 2019). In western Iran, it inhabits in subtropical Quercus forests from 1100 up to 1750 m (Petschenka et al, 2006). The species is caught in Quercus forest with Paliurus spina-christi, Pistacia and Juniperus species from $1160 \mathrm{~m}$ in a mountainous region from south-east Anatolia Region of Turkey.

Distribution. South-western Bulgaria (Kressna gorge), northern Greece, western Iran (Lorestan and Kermanshah) (Ganev, 1987; Petschenka et al, 2006; Leraut, 2009; Müller et al, 2019), and south-eastern Turkey (new discovered). Müller et al. (2019) in the distribution of the species mentioned as 'South-east European-Anatolian'. However, they did not provide any reference records and unmarked on the map for Anatolia.

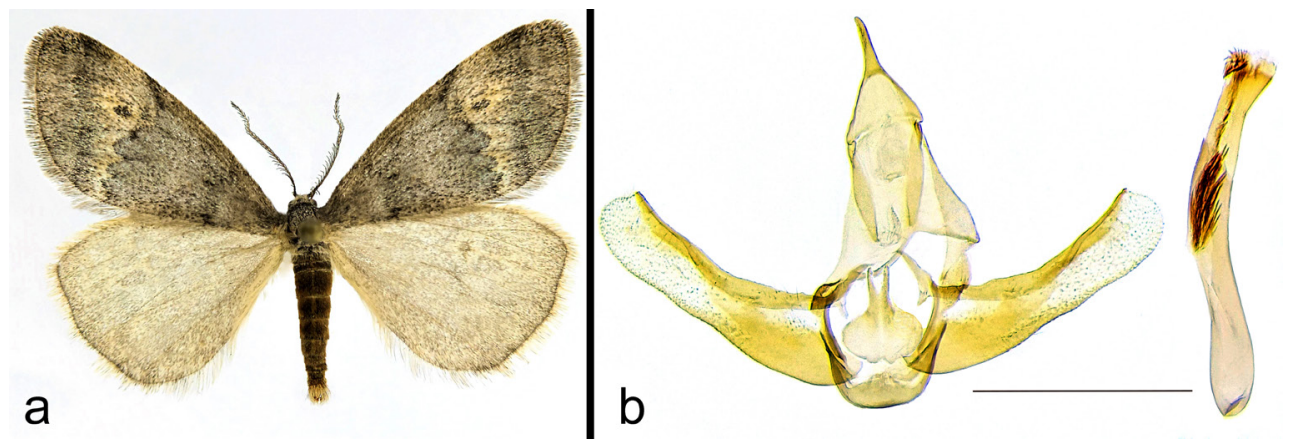

Fig. 1. Male of Kresnaia beschkovi (Ganev, 1987): a. adult, b. genitalia capsule and aedeagus (g. prep 605 , scale bar: $1 \mathrm{~mm}$ ) 


\section{DISCUSSION}

There is no similar and closely related species of Kresnaia beschkovi (Ganev, 1987 ) in Europe and Turkey. It could be clearly distinguished from its external and internal morphological characters. Definable from the genus Agriopis Hübner, 1825 primarily by its forewing lines, color of wings and, long uncus, apically rounded valva, two bunches of small cornuti in the vesica of male genitalia structure. The included in a multi-gene analysis, COI data suggest an isolated phylogenetic lineage and, genetic data not suggesting any closer relationship with any Palaearctic Ennominae Duponchel, 1845 genus for Kresnaia Leraut, 2009 (Müller et al, 2019).

Kresnaia beschkovi is an extremely local species and limited distribution in Europe (Müller et al, 2019). It has also very small population in south-eastern Turkey for the present. However, it is a pest species, the larvae defoliate the oak plants in Iran (Petschenka et al, 2006). The species has been noted to be the dominant species, compared to other oak-feeding moth species. Known parasites of the species are fungi and Hymenoptera (Ichneumonidae) (Petschenka et al, 2006).

Being active during the cold months and low population of the species are probably cause the difficulties in determining its range. The presence of the species in Bulgaria, Greece, western Iran and southeastern Turkey, suggesting that it is likely to be found in other regions of Turkey. The species could possibly extend its distribution to northern Iran, northern Iraq, and north-eastern Syria.

\section{References}

Ganev, J. (1987). Eine neue Geometriden-Art aus Bulgarien, Agriopis beschkovi sp. n. (Lepidoptera, Geometridae, Boarmiinae). Entomofauna, 8(18), 273-275.

Koçak, A.Ö. \& Kemal, M. (2018). A synonymous and distributional list of the species of the Lepidoptera of Turkey. Centre for Entomological Studies Memoirs, 8, 1-487.

Leraut, P. (2009). Moths of Europe. Volume 2, Geometrid moths. N.A.P. ed.: Verrières-le Buisson.

Müller, B. (1996). Geometridae. In O. Karsholt \& J. Razowski (Eds.), (pp. 218-249.) The Lepidoptera of Europe. A distributional checklist. Apollo Books, Stenstrup.

Müller, B., Erlacher, S., Hausmann, A., Rajaei, H., Sihvonen, P., \& Skou, P. (2019). Geometrid Moths of Europe, vol. 6, Ennominae II. Leiden: Brill.

Petschenka, G., Tavakoli, M. \& Trusch, R. (2006). Description of the unknown female of Agriopis beschkovi Ganev, 1987 (Geometridae: Ennominae), and illustration of the larvae. Nota lepidopterologica, 29(1/2), 27-35.

Republic of Turkey Ministry of Agriculture and Forestry, (2020). General Directorate of Meteorology. https:// www.mgm.gov.tr/veridegerlendirme/il-ve-ilceler-istatistik.aspx?m=BATMAN (Accessed date, 14/09/2020)

Robinson, G.S. (1976). The Preparation of slides of Lepidoptera genitalia with special reference to the Microlepidoptera. Entomologist's Gazette, 27, 127-132.

Scoble, M. J. (ed.) (1999). Geometrid moths of the world - a catalogue, 2 vols. Apollo Books: Stenstrup.

Seven, E. (2019). First comprehensive faunistic list on the Lepidoptera species of Batman province (Southeastern Turkey). Munis Entomology \& Zoology, 14(2), 439-447. 